ISSN: $1576-0162$

http://dx.doi.org/10.33776/rem.v0i58.4878

\title{
On the Vulnerability of ECONOMies to Covid-19: An EMPIRICAL ApPROACH
}

SOBRE LA VULNERABILIDAD DE LAS ECONOMÍAS A LA COVID- 19:
UNA APROXIMACIÓN EMPÍRICA

Carmen Díaz Roldán'

Universidad de Castilla-La Mancha and Instituto de Economía Internacional carmen.diazroldan@uclm.es

José María Pérez de la Cruz Universidad de Castilla-La Mancha JoseMaria.Perez@alu.uclm.es

María del Carmen Ramos Herrera Universidad Autónoma de Madrid mariac.ramos@uam.es

Recibido: junio 2020; aceptado: noviembre 2020

\section{ABSTRACT}

During the confinement due to the Covid-19 crisis, economies survived thanks to the available technology and changes of the production model. To study the vulnerability of economies against the challenges of the recovery, in this paper we study the role of some factors related to the development of productive sectors, the use of technology, and the structure of public finances. Using panel data estimations for the European Union, we identify some characteristics that would help economies to boost economic growth. We find that the employment in sectors with a high technological content is the variable that most drives output growth.

Keywords: Covid-19 crisis, recovery, panel data.

1 Carmen Díaz-Roldān acknowledges the financial support received by the Universidad de Castilla-La Mancha (Project 2020-GRIN-29041, co-financed by the European Union via the European Regional Development Fund). 
RESUMEN

Durante el confinamiento de la poblaciōn debido a la crisis del Covid-19, las economías han sobrevivido gracias a la tecnología disponible y a cambios en el modelo productivo. Para estudiar la vulnerabilidad de las economías frente a los retos de la recuperación, en este trabajo, estudiamos el papel de algunos factores relacionados con el desarrollo de los sectores productivos, el uso de la tecnología y la estructura de las finanzas públicas. Haciendo uso de estimaciones de datos de panel, para la Unión Europea, identificamos algunas características que ayudarían a las economías a impulsar el crecimiento económico. Encontramos que el empleo en sectores con un alto contenido tecnológico es la variable que más impulsa el crecimiento de la producción.

Palabras clave: Covid-19 crisis, recuperaciōn, datos de panel.

JEL Classification / Clasificación JEL: C23, F43, O38, O4. 


\section{INTRODUCTION}

In December 2019 in Wuhan (Hubei Province, China), numerous cases of pneumonia caused by an unknown type of coronavirus were detected and throughout the month of January 2020, the World Health Organization (WHO) published the first documents on outbreaks and the first guidelines for managing potential outbreaks (WHO, 2020a). In late January and during the month of February, infections outside China increased and on March 11, 2020, the Director General of WHO announced that the disease caused by the new coronavirus, called Covid-19, was declared a pandemic (WHO, 2020b).

Among the strategies to mitigate the effects of the pandemic, it is recommended that when cases are detected, the immediate isolation of patients, a rigorous monitoring of contacts, social distancing, quarantine, and even the confinement of the population should be carried out. Prevention and control measures that are expected to be necessary include the use of masks for the general population, social distancing, the closure of educational and work centres, voluntary and even mandatory quarantine (WHO, 2020c).

Given the proliferation of infections, during the first fortnight of March there were several countries around the world that successively proceeded to order the closure of schools, workplaces, impede the mobility of the population and force the strict confinement of the population, in the face of the collapse of health systems. Only essential activities directly related to food and healthcare were allowed. It was an unprecedented situation that, globally, was simultaneously causing a health, economic and social crisis.

The repercussions at the economic level were immediate. The containment measures initially taken in China provoked a supply shock that directly affected global value chains and, therefore, contributed to the fall in industrial output worldwide. To this should be added the interruption of the regular development of work due to the population's mobility restrictions, which reduced production and reinforced the negative supply shock. The confinement of the population translated in turn into a decrease in demand. And to all this can be added with effects that are expected to be felt in the medium and even long term - a drop in income at the level of both business and domestic economies. This situation has caused liquidity restrictions and access to credit, with the risk of extending the negative economic effects beyond overcoming the health crisis (Valle, 2020). 
During the confinement of the population, only the production levels of basic resources and those obtained through telework have been maintained. Specifically, only the distribution of basic goods (food, medicine and health products), education and other services have been allowed, and only if they could be offered remotely. It has been a widely observed fact that, in the Covid-19 crisis, the survival of economies has been based on the availability of access to technology and on the technological skills of the population to adapt to change. This unprecedented turn to the use of technology has not only been a key factor in the degree of resilience of the countries, but will also have repercussions on the current production model, since as a precautionary measure the work of the future will be even more reoriented towards activities based on the use of technology.

In these unprecedented circumstances, the most vulnerable economies (which will lose more and take longer to recover) are those that are highly dependent on the low-technology services sector (some activities linked to tourism, for example); their sectoral specialization is based on activities with scarce technological components; they have populations with less access to technology (greater digital gap), and who are less trained in technological skills (less social capability), and they have high deficit and public debt ratios, since they will have more difficulty in facing the increase in public spending and access to credit.

Given the moment in which we find ourselves, just at the dawn of the changes caused by the Covid-19 crisis, the objective of our study will be to infer what are the characteristics of the economies that, given the previous arguments, will favour the economies to be less vulnerable to the economic effects of this crisis. To do this, we will analyse how certain variables have contributed to the growth of output in a group of countries in the years after the 2008 economic crisis. In other words, we are going to study what were the factors that contributed to recovery and growth during recent years. The variables of interest will be grouped into the areas that have proved to be crucial for the subsistence of the economies in the midst of the Covid-19 crisis: the development of the productive sectors, the use of technology, and the structure of public finances.

What we will try to verify in our work is the degree of dependence of economies on certain factors that, from different perspectives, can contribute to economic growth. We will base our empirical analysis on various theoretical approaches, since there are many factors that can contribute to economic growth. This can be seen in the contributions of various authors and schools of thought in the literature on economic growth. The thesis that we propose is that those countries that have had and have greater access to technology and make better use of it, will have more facility to face the changes and will have been less vulnerable to the economic crisis derived from the pandemic.

The organization of the work is as follows: in the next section we will review some of the literature that, from different approaches, analyses the factors that contribute to economic growth along the lines already mentioned. In Section 
3 we will detail the methodology used in our analysis, as well as the empirical exercise. In Section 4 the obtained results will be discussed and, finally, in Section 5 we will show the summary and conclusions of the study.

\section{THe FACTORS OF ECONOMIC GROWTH: SOME LITERATURE ON THE TOPIC}

We will group the factors that can contribute to economic growth into three blocks: the structure of the productive sectors; the labour market and the living conditions of the population; and the characteristics of the public sector.

\subsection{Productive SECTORS AND ECONOMIC GROWTH}

In the literature on economic growth, one of the arguments to explain the different evolution of economies over time has been differences in productivity. Already in the sixties of the last century, according to the thesis defended by Kaldor (1961), the so-called Kaldor laws maintained that the development of the manufacturing sector was the driving force of economic growth. The argument was based on the empirical regularity with which the manufacturing industry showed increasing returns, while the agriculture sector presented decreasing returns. In addition, it was observed that the productivity growth rates per worker had differed between countries, which reinforced the hypothesis that the countries that registered the highest growth were those in which the manufacturing sector was the leading sector. In this sense, Kaldor's laws pointed to capital factor accumulation (physical capital in its traditional sense) and technological progress as drivers of growth (Bajo-Rubio and DiazRoldān, 2011: chap. 12).

These arguments continue to be in force, since the growth of labour productivity currently continues to play a fundamental role in aggregate economic growth, particularly the growth of labour productivity in industry and services that have incorporated technological progress. Reuveny and Thompson (2001) had shown how the economies handling growth worldwide are those that promote innovations in the leading sectors. And that the growth of key sectors not only encourages aggregate growth at the domestic level, but also stimulates it at the international level. The starting assumption is that innovations drive growth. And that the leading sectors are those that incorporate high technological content.

From a different perspective, Dulcich (2018) reconciles the structuralist doctrine with the theories of economic growth, showing that they are not incompatible. According to structuralists, the technological dependence of developing countries limits their development, while the theories of economic growth indicate that technological development is determined by the educational level of the population and the ability to finance innovation. The differences in these factors are the cause of the non-convergence of the growth 
rates of the countries. The author highlights that industrialisation was the traditional vehicle to generate innovations. But today technological innovations are not only present in machinery and its technical components, but in services such as patents and those related to computing. The adoption of technology increases labour productivity and favours economic growth. Although the final impulse to reach advances countries requires acquiring the status of technology supplier at the international level. In fact, in the coming years growth will be determined by productivity growth, provided that the leading sectors generate added value and can offer good-quality jobs (ILO, 2019).

From Kaldor's doctrine to the structuralist one, it seems that the countries that could best overcome the general decrease in output, due to the Covid-19 crisis, are those that have a higher level of technological development and a greater endowment in terms of human capital.

\subsection{TECHNOLOGY AND LABOUR MARKET}

Regarding the implications of technology on the labour market, Zeira (1998) pointed out that the countries with high productivity are those that adopt technological innovations, which explains the differences in production per capita among countries. In addition, the endogenous growth approach (Helpman, 2004) indicates that the engine of economic growth is the externalities of capital that promote the dissemination of knowledge. In fact, in the last decades, technological advances have transformed productive activities, and, in this context, the labour market demands workers capable of adapting to technological advances. From this perspective, human capital plays a much more prominent role today in explaining technological progress and its impact on labour productivity (Jorgenson and Stiroh (2000); and Jorgenson (2001)). So much so that, years later, Jones and Romer (2010) updated the already mentioned Kaldor's laws and pointed to institutions, the flow of ideas, the population and human capital as explanatory factors for economic growth among developed countries.

In a recent study, Pianta (2018) shows an overview of the main empirical regularities that technological changes produce in employment. In emerging economies, technological change consists of the acquisition and imitation of components with a high technological content and results in greater economic growth if there is an adequate institutional framework and the population is properly trained. Institutional suitability requires public policies that facilitate access to financing for the production system and research. And the social capability of the population refers to the technical competence of the population, in line with the hypothesis of the technological approach (Abramovitz, 1986), and which is measured by the educational level of the population (Bajo-Rubio and Díaz-Roldán, 2011; chap. 12).

From another point of view, Kay and Vanborren (2018) analyse the impact of digitization on flexible jobs (self-employment, part-time and temporary 
employment) in Organisation for Economic Cooperation and Develoopment (OECD) countries. As a proxy for digitization, they use the added value of the Information and Communication Technologies (ICT) sector as a proportion of gross domestic product (GDP). Their results show that as the added value of ICT increases, flexible jobs increase. And De la Cámara (2000) has recently analysed the change in the labour market due to the emergence of telework. The evolution of the labour market showed how, after the economic crises of the 70s, the limited expansion of new technologies during those years, prevented the rise of telework on which great expectations had been created, and how the availability of infrastructure and the training of potential workers put a brake on the expansion of telework and its contribution to the growth and development of the regions. The growth generated by teleworking is based on the greater flexibility of production and business organization, which derives from work and translates into greater competitiveness. The conclusion of the study underlines the need for public policies to focus on ensuring that the benefits of technology reach all citizens.

These conclusions are even more valid today. The telework option has not been proposed as an alternative but has been imposed as an inexcusable obligation to maintain production during the confinement required to face the Covid-19 crisis. As shown, several theoretical and empirical approaches point to technology as a key factor to improve labour performance and, therefore, contribute to economic growth. And in line with the above, the most vulnerable economies will have been those where there is a lack of productive models with high technological endowment, and in which the digital divide is wider, both in terms of training of individuals and their access to technologies.

\subsection{THE GOVERNMENT SECTOR}

The relationship between government expenditure, and government deficit, and economic growth is a recurrent topic in the literature on economic growth and public economics. Despite of that, some years ago, Díaz-Roldān and Martínez-López (2006) pointed out that theoretical models confirm that public capital provision contributes to economic growth while generating positive externalities for the private sector. Similarly, empirical studies also generally show a positive effect of public investment on economic growth. Later, and from another point of view, Ardagna et al. (2007) advised on the danger of excessive fiscal laxity leading to unsustainable deficits. They stressed how expansionary fiscal policies raise interest rates in the short run, but also that government deficits and debt would affect interest rates in the long run. The increase in the interest rates and the magnitude of the crowding-out effect, decreasing private investment and consequently depressing the capital stock, would depend on the accumulation of past and expected future fiscal deficits. Moreover, in the current environment of low interest rates, expansionary policies have a limited effect, while large deficits and huge debt stocks create expectations of future 
fiscal austerity. Expectations regarding future fiscal adjustments would prevent people from present consumption, inducing them to show a Ricardian attitude (Barro, 1974).

In a recent working paper, Auerbach et al. (2020) have evaluated the effects of Covid-19 restrictions and the role of fiscal policy. The authors warn about the transfers to households and firms, given that the effects will depend on the spending multipliers of each economy.

But in addition to the problems that excessive government deficits could create, we should mention the external deficit. In this sense, Thirlwall's (1979) thesis sustained that the evolution of the balance of payments could turn into a constraint to economic growth. The basis of this thesis is that unsustainable external deficits will require a correction that will limit the output growth (via a reduction in the aggregate demand or via a depreciation of the exchange rate). In fact, the relationship between the fiscal policy and the current account balance constitutes one of the central issues in the literature on international economics. To such an extent that has led to the formulation of the so-called twin deficits hypothesis (see Miller and Russek, 1989; Bongers and Torres, 2017; Bird et al., 2019, among others). The assumption of the twin deficits hypothesis is that given the equilibrium of the private sector, the government deficit is proportional to the current account deficit.

As can be seen, government expenditures, government and external deficits prove to be key factors of economic growth and, consequently of recovery after a crisis. But the limit to the potential benefits could arise from unsustainable government deficits, and also from unsustainable external deficits. Hence the importance of avoiding excessive deficits.

\section{METHOdOLOGY AND EMPIRICAL APPLICATION}

As stated in the Introduction, we will analyse the extent to which certain variables have contributed to the growth of output after the 2008 economic crisis. The idea is to identify the dependence of growth of some of the factors that contributed to recovery and growth during the last few years. We have grouped the factors into three sets according to the different approaches shown in the outlined literature on economic growth: the structure of the productive sectors; the labour market and the living conditions of population; as well as the characteristics of the public sector. And from the analysis of the contribution of some representative variables of those sets, we will try to identify, in an indirect way, what type of country would be more vulnerable to cope with the Covid-19 crisis. For our empirical analysis we will use data on the 27 European Union (EU) countries taken from Eurostat. The period covers the years from 2008 to 2019.

Given the characteristics of our sample, we will apply panel data techniques to estimate the degree to which certain factors have contributed to economic growth during the period of recovery of the financial crisis of 2008. According 
to Baltagi (2008), the main advantages over single cross-sections or time series data are the following: a) more accurate inference of model parameters; b) greater capacity for capturing the complexity of economic relationships; c) more informative results; d) the ability to control for individual unobserved heterogeneity; and e) the simpler computation and statistical inference. More details about the strengths and weaknesses of using panel data are discussed in Hsiao (2014) or AndreB et al. (2013). To estimate our panel, we consider three basic panel regression methods: fixed effects (FE), random effects (RE) and pooled-OLS (POLS).

The first method is the FE model, which consists of estimating the following regression:

$$
\mathrm{y}_{\mathrm{it}}=\alpha_{\mathrm{it}}+\mathrm{x}_{\mathrm{it}} \beta+\varepsilon_{\mathrm{it}} \quad \text { for } i=1, \ldots, N, \quad t=1, \ldots, T
$$

where $x_{i t}$ is a $(k-1) \times 1$ vector of explanatory variables without constants or any time-invariant variables. In addition, $\alpha_{i}$ captures the unobservable individual (cross section) heterogeneity and constant over time, and $e_{i t}$ is idiosyncratic errors with $e_{i t} \sim \operatorname{IID}\left(0, \sigma^{2}\right)$. The error term is assumed to be uncorrelated with the explanatory variables of the current, the past and future periods of the same country.

In the FE model, the unobserved individual specific effect is allowed to be correlated with the explanatory variables and it is based on the assumption of strict exogeneity $\left[E\left(x_{i t} e_{i t}\right)=0\right.$ for $\left.s=1, \ldots, T\right]$.

The second estimation method is the RE model. This model is also called ANOVA II or variance components model. Its estimator is the feasible generalized least squares (GLS). The main characteristic is that the variation across countries is assumed to be random and uncorrelated with regressors. Concretely, Green (2008) emphasizes that the crucial difference between fixed and random effects is the no correlation, but not whether the individual effects are stochastic or not. Another advantage of using random effect estimator is that it is possible to include time invariant variables in the model.

Finally, the third method is the POLS in which $\alpha_{i}$ needs to be uncorrelated with $x_{i t}$ and also $E\left(x_{i t} e_{i t}\right)=0$ must be satisfied. In this case, we simply apply OLS to the grouped data. The POLS estimator ignores the panel structure of the data.

Furthermore, with the aim of determining which is the best method to estimate our model, we make use of three statistic tests. First, we implement the $\mathrm{F}$ test to analyse whether all unobservable individual effects are equal to zero. Using this test, we will be able to select between FE or POLS. Second, to discriminate between RE and POLS we apply the Lagrange multiplier test by Breusch and Pagan (1980) with the purpose of identifying the existence of an unobserved effect. Finally, the hypothesis of no correlation between the regressors and the unobservable effects is considered using the Hausman test. In the case in which there is no correlation, FE and RE are both consistent but FE is inefficient and in the opposite scenario, FE is consistent and RE inconsistent. 


\subsection{Variables and Data Set}

In our empirical analysis we have used time series of data of the following variables taken from Eurostat, from the years 2008 to 2019. As the dependent variable we have chosen:

GDPG: Gross domestic product growth

And as the independent variables, we have chosen the variables related with the three blocks we have addressed to review the literature, from which data are available for all the countries and for the whole period analysed. The variables are as shown below.

Variables related to productive sectors:

MAF: Manufacturing

Value added of manufacturing as percentage of GDP.

TOUR: Tourism

Value added of activities related to touristic services (wholesale and retail trade, transport, accommodation, and food service activities) as percentage of GDP.

NFS: Non-financial Services

Value added of non-financial services (professional, scientific, and technical activities, administrative and support service activities) as percentage of GDP.

Variables related to technology and labour market:

HTKE: High technology and knowledge employees.

Employment in technology and knowledge-intensive sectors (hightechnology manufacturing and knowledge-intensive high-technology services), as percentage of total employment.

IAH: Internet access by households

Percentage of households with Internet access.

Variables related to the public sector:

GDEF: Government deficit.

Government deficit/surplus of general government.

Net lending $(+)$ /net borrowing $(-))$, as percentage of GDP.

BOP: Balance of payments position.

Current plus capital account balance (net lending $(+) /$ net borrowing $(-))$, as percentage of GDP. 


\section{ESTIMATION RESULTS}

Table 1 shows the estimation results of the three proposed methods.

Table 1. Panel regressions: All countries

\begin{tabular}{|c|c|c|c|}
\hline Dependent variable GDPG & Pooled OLS & Fixed effects & Random effects \\
\hline Constant & $\begin{array}{r}-11.8403^{*} \\
(2.6183)\end{array}$ & $\begin{array}{r}-33.9423^{*} \\
(5.4990)\end{array}$ & $\begin{array}{r}-15.6045^{*} \\
(2.9402)\end{array}$ \\
\hline \multicolumn{4}{|l|}{ Productive sectors } \\
\hline MAF & $\begin{array}{l}0.1825^{*} \\
(0.0541) \\
\end{array}$ & $\begin{array}{l}0.6495^{*} \\
(0.1219) \\
\end{array}$ & $\begin{array}{l}0.2326^{*} \\
(0.0540) \\
\end{array}$ \\
\hline TOUR & $\begin{array}{l}0.2828^{*} \\
(0.0696)\end{array}$ & $\begin{array}{l}0.5570^{*} \\
(0.1899) \\
\end{array}$ & $\begin{array}{l}0.3482^{*} \\
(0.0909) \\
\end{array}$ \\
\hline NFS & $\begin{array}{r}0.1657^{* *} \\
(0.0828) \\
\end{array}$ & $\begin{array}{r}0.6616^{* *} \\
(0.2851) \\
\end{array}$ & $\begin{array}{r}0.1762 \\
(0.1418) \\
\end{array}$ \\
\hline \multicolumn{4}{|c|}{ Labour market and living conditions } \\
\hline HTKE & $\begin{array}{r}0.4962 * * \\
(0.2467) \\
\end{array}$ & $\begin{array}{l}1.6204^{*} \\
(0.6060)\end{array}$ & $\begin{array}{r}0.5271^{* *} \\
(0.2590) \\
\end{array}$ \\
\hline $\mathrm{IAH}$ & $\begin{array}{r}0.0437 * * * \\
(0.0244) \\
\end{array}$ & $\begin{array}{r}0.0613^{* *} \\
(0.0268) \\
\end{array}$ & $\begin{array}{l}0.0647^{*} \\
(0.0223) \\
\end{array}$ \\
\hline \multicolumn{4}{|l|}{ Public sector } \\
\hline GDEF & $\begin{array}{l}0.3718^{*} \\
(0.0968)\end{array}$ & $\begin{array}{l}0.2157^{*} \\
(0.0672)\end{array}$ & $\begin{array}{l}0.3548^{*} \\
(0.0571) \\
\end{array}$ \\
\hline BOP & $\begin{array}{r}-0.1442 * * \\
(0.0620) \\
\end{array}$ & $\begin{array}{r}-0.1279 * * \\
(0.0545) \\
\end{array}$ & $\begin{array}{r}-0.1367^{*} \\
(0.0491) \\
\end{array}$ \\
\hline $\mathrm{R}^{2}$ within & & 0.3864 & 0.3484 \\
\hline $\mathrm{R}^{2}$ between & & 0.2707 & 0.2469 \\
\hline $\mathrm{R}^{2}$ overall & 0.2971 & 0.1951 & 0.2922 \\
\hline $\begin{array}{l}\text { Haussman test } \\
\text { (FE vs RE) }\end{array}$ & & & $\begin{array}{r}42.44^{*} \\
{[0.0000]} \\
\end{array}$ \\
\hline $\begin{array}{l}\text { Breusch and Pagan test } \\
\text { (POLS vs RE) }\end{array}$ & & & $\begin{array}{r}15.31^{*} \\
{[0.0000]}\end{array}$ \\
\hline $\begin{array}{l}F \text { test for fixed effects } \\
\text { (POLS vs FE) }\end{array}$ & & & $\begin{array}{r}3.71^{*} \\
{[0.0000]}\end{array}$ \\
\hline Observations & & & 324 \\
\hline
\end{tabular}

Notes: In the ordinary brackets below the parameter estimates are the corresponding z-statistics, computed using White (1980)'s heteroskedasticity-robust standard errors. In the square brackets below the specification tests are the associated $p$-values. ${ }^{*}, * *$ and $* * *$ indicate significance at $1 \%$, $5 \%$, and $10 \%$ respectively.

Source: Own elaboration from Eurostat data using the methodology indicated in the text.

Given the results of the three statistic tests we have performed (Haussman Test, the Breusch and Pagan Test, and the F Test for fixed effects) it can be stated that the best estimation method is FE. According to this model, the explanatory variables are significant at the significance level of $1 \%$ and $5 \%$.

Regarding the three sectoral variables, it can be seen how they all contribute significantly to the growth of the GDP. The proportion to which they contribute is similar, although non-financial services show a slightly higher coefficient, but at a level of significance of $5 \%$. 
The employment in sectors with a high technological content is the variable that most drives output growth, with a coefficient slightly more than double that associated with non-financial services. Furthermore, it is significant at $1 \%$. That result is in line with the literature we have reviewed in previous sections. On the other hand, the proportion of households with Internet access, although it has a positive and significant effect, does not have as much weight in the growth of production. The reason could be found in the fact that the availability of Internet access does not necessarily imply a use that generates added value.

The variable capturing the government deficit or surplus shows a positive and significant coefficient, although its contribution to economic growth hardly represents a third of that shown by the sectoral variables. In the analysed period, the average of the aggregate budgetary balance of the countries that compose the sample was $-2.69 \%$. In other words, the EU countries had deficit government balances, but the public spending would have been contributing to production growth.

Whit respect to the external position, the combined balance of the current account and capital balances has a negative effect on growth. This result is in line with Thirlwall's (1979) thesis on the constraint to economic growth induced by the balance of payments. In the analysed period, the average of the combined balance of the current account and capital balances of the countries that form the sample was $1.04 \%$. However, 16 of the 27 member states show an external deficit or a negligible surplus (see Table 8 ahead). These results are aligned with those obtained by Bajo-Rubio and Díaz-Roldān (2009, 2012), who analysed Thirlwall's (1979) thesis for some European countries, and whether the export-led growth hypothesis was confirmed. Their results showed that, with some exceptions, some European countries ran external deficits that might become unsustainable in the long run. And, also, that, despite the growth experienced by European countries, the export-led growth hypothesis was not confirmed and the observed growth was due to other factors.

\section{1. ThE HETEROGENEITY OF THE COUNTRIES AND THEIR VULNERABILITY}

From the estimation results shown in Table 1, we know what have been some of the factors that have contributed to economic growth of the EU countries since from 2008. That gives us some information about the ways of recovery after the last financial crisis. But as stated in the introduction, the aim of this paper is to ascertain to what extent some of those factors could contribute to recovery after the current Covid-19 crisis and what would be the characteristics featuring in the resilience of the countries.

Our preferred method of estimation, the FE method, allows us to extract the unobserved and invariant heterogeneity of each country of the data set. In Table 2 we show the fixed part of the idiosyncratic errors, according to FE estimation. We can see how, although the average values of the explanatory variables within countries are equal (as shown in Table 1), the average values 
of the independent term are different, although these figures are equal for the Netherlands and Slovakia (-0.97) and for Portugal and Romania (3.6).

The figures shown in Table 2 give us some information on the heterogeneity of how the economic growth of EU countries, respond to the explanatory variables of our analysis even when the coefficients of the estimation are equal.

Summing up the results of Table 1, the GDP growth of the EU countries has been favoured by the expansion of the manufacturing sector, the services sector, the non-financial sector, the employment in high-tech and intensiveknowledge sector, the government deficit and, to a lesser extent, to access to the Internet, while the external position does not seem to have played the best role.

To what extent would the analysed group of countries respond successfully to the Covid-19 crisis? We could say that those countries showing figures of the explanatory variables in better positions than the average of the whole group would be less vulnerable.

In Tables 3 to 8 we show the average values of the variables for each country and the whole period, in relation to the average value of each variable for the EU countries group. We have excluded the variable IAH, given its low contribution to GDP growth.

Given the role played by the manufacturing sector in the rise of production and, consequently, in favouring the economic growth, the countries showing a participation above EU average would be less vulnerable to the Covid-19 crisis, provided that the levels of production prior to confinement were recovered. Under that assumption, and according to the figures we can see in Table 3, the countries best placed would be Ireland, Czechia, and Romania. While in Cyprus, Luxemburg and Greece the manufacturing sector offers a limited contribution to output growth.

Regarding the activities related to touristic services (wholesale and retail trade, transport, accommodation, and food service), the countries whose growth is more linked to those business are Lithuania, Latvia and Poland. In

TABLE 2. The heterogeneity of the COUNTRIES

\begin{tabular}{l|c|l|c|l|c} 
Country & Fixed part & Country & Fixed part & Country & Fixed part \\
\hline Austria & -3.26 & France & 0.84 & Malta & 1.59 \\
\hline Belgium & -3.06 & Germany & -3.59 & Netherlands & -0.97 \\
\hline Bulgaria & 5.29 & Greece & 4.67 & Poland & 1.21 \\
\hline Croatia & 2.39 & Hungary & -1.78 & Portugal & 3.6 \\
\hline Cyprus & 5.98 & Ireland & -8.2 & Romania & 3.6 \\
\hline Czechia & -3.76 & Italy & -0.86 & Slovakia & -0.97 \\
\hline Denmark & -0.66 & Latvia & 1.89 & Slovenia & -4.77 \\
\hline Estonia & -0.82 & Lithuania & -1.64 & Spain & 1.66 \\
\hline Finland & -2.93 & Luxembourg & 6.04 & Sweden & -1.49
\end{tabular}

Source: Own elaboration from data extracted from the estimates of FE. 
Table 3. Maf average values (2008-2019). EU average: 14.30 of value added as \% of GDP

\begin{tabular}{l|r|l|r}
\multicolumn{2}{c|}{ Countries above EU average } & \multicolumn{2}{c}{ Countries below EU average } \\
\hline Austria & 16.75 & Belgium & 12.73 \\
\hline Czechia & 22.72 & Bulgaria & 13.14 \\
\hline Finland & 15.66 & Croatia & 13.07 \\
\hline Germany & 19.95 & Cyprus & 4.68 \\
\hline Hungary & 18.79 & Denmark & 12.00 \\
\hline Ireland & 25.03 & Estonia & 13.57 \\
\hline Italy & 14.44 & France & 10.30 \\
\hline Lithuania & 16.96 & Greece & 8.53 \\
\hline Poland & 16.63 & Latvia & 10.70 \\
\hline Romania & 20.61 & Luxembourg & 5.02 \\
\hline Slovakia & 18.25 & Malta & 9.46 \\
\hline Slovenia & 19.23 & Netherlands & 10.80 \\
\hline & & Portugal & 11.75 \\
\hline & & Spain & 11.43 \\
\hline & & Sweden & 13.83
\end{tabular}

Source: Own elaboration from data extracted from Eurostat.

fact, as can be seen in Table 4, in almost half the EU countries the commercial and touristic services represent around $21 \%$ of GDP, while in the countries below the EU average, the participation rises above 16\%. It seems to be clear that EU economic growth is strongly linked to the evolution of this sector. Therefore, the post Covid-19 recovery will depend highly on the specific road map of the return to activity in each country.

In Table 5 we show the average values of the activities related to nonfinancial services (professional, scientific and technical activities, administrative and support service). Most of them can be supplied by telework and online services. Hence, it could be expected that their contribution has been maintained or even increased during the lockdown. According to the figures, the countries in which the NFS contribution to GDP growth is above the EU average are the Netherlands, France and Malta. On the contrary, Greece, Bulgaria and Lithuania show the lowest figures.

As highlighted in the literature review section, employment in technology and knowledge-intensive sectors proves to be one of the key factors of economic growth. Our empirical results, already shown in Table 1, prove that asseveration, which remains robust under any of the estimation procedures we have conducted. From that, we can conclude that countries leading in the technology and knowledge-intensive sectors would be less vulnerable to an economic crisis, in the sense that during the recovery, they would be able to restart activities of higher productivity, which provide more added value. In Table 6, we can see that, in relation to EU averages, the countries best situated are Ireland, Finland and Malta. And in the worst positions we find Lithuania, Romania and Greece. 
Table 4. TOUR average values (2008-2019). EU average: 18.45 of Value added as \% of GDP

\begin{tabular}{l|r|l|r}
\multicolumn{2}{c|}{ Countries above EU average } & \multicolumn{2}{c}{ Countries below EU average } \\
\hline Austria & 20.49 & Belgium & 17.78 \\
\hline Bulgaria & 18.56 & Croatia & 18.38 \\
\hline Cyprus & 21.53 & Czechia & 16.68 \\
\hline Estonia & 19.36 & Denmark & 17.04 \\
\hline Greece & 21.33 & Finland & 13.93 \\
\hline Italy & 18.63 & France & 15.93 \\
\hline Latvia & 23.02 & Germany & 14.34 \\
\hline Lithuania & 28.02 & Hungary & 15.54 \\
\hline Malta & 19.15 & Ireland & 13.34 \\
\hline Netherlands & 17.68 & Luxembourg & 15.30 \\
\hline Poland & 22.62 & Romania & 15.99 \\
\hline Portugal & 20.99 & Slovakia & 17.73 \\
\hline Spain & 21.08 & Slovenia & 17.73 \\
\hline
\end{tabular}

Source: Own elaboration from data extracted from Eurostat.

Table 5. NFS average values (2008-2019). EU average: 8.15 of value added as \% of GDP

\begin{tabular}{l|r|l|r}
\multicolumn{3}{c|}{ Countries above EU average } & \multicolumn{2}{c}{ Countries below EU average } \\
\hline Austria & 8.33 & Bulgaria & 5.08 \\
\hline Cyprus & 8.23 & Croatia & 7.05 \\
\hline France & 11.85 & Czechia & 6.06 \\
\hline Germany & 10.02 & Denmark & 7.57 \\
\hline Hungary & 7.91 & Estonia & 7.58 \\
\hline Ireland & 9.18 & Finland & 7.20 \\
\hline Italy & 8.57 & Greece & 4.73 \\
\hline Luxembourg & 9.92 & Latvia & 6.58 \\
\hline Malta & 10.28 & Lithuania & 5.73 \\
\hline Netherlands & 12.93 & Poland & 6.77 \\
\hline Slovenia & 8.44 & Portugal & 6.31 \\
\hline & & Romania & 6.11 \\
\hline & & Slovakia & 8.06 \\
\hline & & Spain & 7.49
\end{tabular}

Source: Own elaboration from data extracted from Eurostat. 
Table 6. HTKE average values (2008-2019). EU average: 4.07 \% of total employment

\begin{tabular}{l|r|l|r}
\multicolumn{2}{c|}{ Countries above EU average } & \multicolumn{2}{c}{ Countries below EU average } \\
\hline Czechia & 4.53 & Austria & 3.89 \\
\hline Denmark & 5.38 & Bulgaria & 3.42 \\
\hline Estonia & 4.48 & Croatia & 3.18 \\
\hline Finland & 5.84 & Cyprus & 2.80 \\
\hline Germany & 4.18 & France & 4.03 \\
\hline Hungary & 5.06 & Greece & 2.43 \\
\hline Ireland & 7.95 & Italy & 3.40 \\
\hline Malta & 5.84 & Latvia & 3.08 \\
\hline Slovenia & 5.22 & Lithuania & 2.34 \\
\hline Sweden & 4.96 & Luxembourg & 3.94 \\
\hline & & Netherlands & 3.85 \\
\hline & & Poland & 2.91 \\
\hline & & Portugal & 2.59 \\
\hline & & Romania & 2.37 \\
\hline & & Slovakia & 3.98 \\
\hline & & Spain & 3.58
\end{tabular}

Source: Own elaboration from data extracted from Eurostat.

Table 7. GDEF average values (2008-2019). EU average: -2.69 as \% of GDP

\begin{tabular}{l|r|l|r}
\multicolumn{2}{c|}{ Countries above EU average } & \multicolumn{2}{c}{ Countries below EU average } \\
\hline Belgium & -2.80 & Austria & -1.93 \\
\hline Croatia & -3.51 & Bulgaria & -0.83 \\
\hline Cyprus & -2.98 & Czechia & -1.57 \\
\hline France & -4.25 & Denmark & -0.24 \\
\hline Greece & -6.20 & Estonia & -0.42 \\
\hline Hungary & -3.03 & Finland & -1.36 \\
\hline Ireland & -7.18 & Germany & -0.12 \\
\hline Italy & -2.96 & Luxembourg & 1.32 \\
\hline Latvia & -2.84 & Malta & -1.18 \\
\hline Lithuania & -2.76 & Netherlands & -1.76 \\
\hline Poland & -3.51 & Sweden & 0.07 \\
\hline Portugal & -5.08 & & \\
\hline Romania & -3.90 & & \\
\hline Slovakia & -3.46 & & \\
\hline Slovenia & -3.92 & &
\end{tabular}

Source: Own elaboration from data extracted from Eurostat.

As proved by the results in Table 1, the government deficit has played a significant role in the recovery of EU countries after the financial crisis of 2008. The positive contribution means that there is room for manoeuvre when economies need to increase government expenditure. The possible constraint appears if deficits turn to be unsustainable, and from that we could conclude 
Table 8. BOP average values (2008-2019). EU average: 1.04 as \% of GDP

\begin{tabular}{l|r|l|r}
\multicolumn{2}{c|}{ Countries above EU average } & \multicolumn{2}{c}{ Countries below EU average } \\
\hline Austria & 2.26 & Belgium & 0.22 \\
\hline Denmark & 6.73 & Bulgaria & -0.02 \\
\hline Estonia & 2.65 & Croatia & -0.28 \\
\hline Germany & 6.98 & Cyprus & -5.08 \\
\hline Hungary & 2.87 & Czechia & 0.32 \\
\hline Lithuania & 1.77 & Finland & -0.48 \\
\hline Luxembourg & 5.18 & France & -0.67 \\
\hline Malta & 3.33 & Greece & -4.03 \\
\hline Netherlands & 8.19 & Ireland & -4.45 \\
\hline Slovenia & 2.39 & Italy & 0.38 \\
\hline Sweden & 4.60 & Latvia & 0.88 \\
\hline & & Poland & -0.63 \\
\hline & & Portugal & -1.64 \\
\hline & & Romania & -2.44 \\
\hline & & Slovakia & -0.95 \\
\hline & & Spain & -0.01
\end{tabular}

Source: Own elaboration from data extracted from Eurostat.

that countries showing deficits (in absolute value) above the EU average would be more vulnerable. Looking at Table 7, we find Italy, Spain and Greece in that position. In contrast, countries showing surpluses or negligible deficits could do a better job; this is the case of Luxemburg, Sweden and Germany.

When considering the external position, the net lender countries will face the adverse situation of Covid-19 crisis more successfully. As we can show in Table 8, The Netherlands, Germany and Denmark show external surpluses, while Cyprus, Ireland and Greece, present external deficits.

\section{Summary and Conclusions}

The economic implications of the confinement due to the Covid-19 crisis have not been trivial. The global supply chains have been interrupted, industrial production reduced, and the regular demand decreased because of mobility restrictions and difficulties in accessing credit of those who have lost their job. Economies are surviving thanks to the available technology and some changes to the production model. The unprecedented turn to the use of technology has been a key factor in the maintenance of production of basic resources, educational activities and services provided through teleworking.

Bearing in mind that recovery will be driven by the factors that have sustained production, in this paper we have tried to identify some characteristics that would help economies to boost economic growth. Our assumption is that those countries with access to technology and able to make a better use of 
it, will have more facility to face the changes and will be less vulnerable to the economic crisis caused by the pandemic.

The variables of interest were grouped into the areas of the development of the productive sectors, the use of technology, and the structure of public finances. Using data on the European Union countries, we have studied the factors that contributed to recovery and growth after the 2008 economic crisis. Based on panel data estimations, we find that the employment in sectors with a high technological content is the variable that most drives output growth.

Next, attempting to characterize the economies that, according to our assumptions, could be more (or less) vulnerable to the Covid-19 crisis we have performed a comparative analysis. Based on the estimation results of each variable, we have grouped the countries of our data set into two groups. Our assumption is that those countries showing levels above the average values of the key variables would be less vulnerable to the effects of the crisis because they could reactivate their economies using the factors that have proved to contribute to enhance growth. The results of this comparative analysis confirm the heterogeneity of the countries belonging to the EU, although it is worth noting the case of Greece that would be classified as vulnerable in five of the six variables analysed.

To summarize our findings, we could say that, in spite of the heterogeneity of the EU countries, the main driving force of recovery and economic growth after the financial crisis of 2008 was the employment in sectors with a high technological content. That factor was followed by the expansion of the non-financial services sector, manufacturing and, to a lesser extent, the use of government deficit. Given that during the lockdown in the Covid-19 crisis only the basic and remote-distance activities have been permitted, we could deduce that there will be changes in the current production model, and the work of the future will be reoriented towards the technology and knowledgeintensive sectors. The most immediate implication of economic policy points to public policies focusing on promoting the adoption of technology. The ways are broad: promoting the incorporation of high technological components into production, encouraging and facilitating the training of workers in technological skills, and providing access to technology to the population.

However, our results correspond to a very preliminary phase of the Covid-19 crisis analysis. We have found limitations in the data set and it would be interesting to perform similar studies from a broader time perspective. We have concentrated on some certain variables, based on the literature on economic growth, but there are others that could be considered as a natural extension of this paper.

\section{REFERENCES}

Abramovitz, M. (1986). Catching up, Forging Ahead, and Falling behind, Journal of Economic History 46, 385-406. 
AndreB, H.-J., Golsch, K. and Schmidt, A. W. (2013). Applied Panel Data Analysis for Economic and Social Surveys. Springer-Verlag, Berlin Heidelberg.

Ardagna, S., Caselli, F., and Lane, T. (2007). "Fiscal Discipline and the Cost of Public Debt Service: Some Estimates for OECD Countries” The B.E. Journal of Macroeconomics 7(1),1-35.

Auerbach, A., Gorodnichenko, Y., and Murphy, D. (2020). Fiscal Policy and COVID19 Restrictions in a Demand-Determined Economy, NBER Working Paper 27366.

Bajo Rubio, O. and Díaz Roldān, C. (2009). "Does the Balance of Payments Constraint Economic Growth? Some Evidence for the New EU Members", Post-Communist Economies 21, 41-46.

Bajo Rubio, O. y Díaz Roldān, C. (2011). Teoría y política macroeconómica, Antoni Bosch editor, Barcelona.

Bajo Rubio, O. and Díaz Roldān, C. (2012). “Do Exports Cause Growth? Some Evidence for the EU Members", Post-Communist Economies 24, 125-131.

Barro, R. (1974). "Are Government Bonds Net Wealth?", Journal of Political Economy 82, 1095-1117.

Baltagi, B. (2008). Forecasting with Panel Data. Journal of Forecasting, 27 (2), 153-173.

Bongers, A. and Torres, J. (2017). "Fiscal Policy, the Current Account and the Twin Deficits Hypothesis", Cuadernos Económicos de Información Comercial Española 94, 33-56.

Bird, G., Pentecost, E. and Yang, Y. (2019). "The Twin Deficits Hypothesis: an Empirical Examination”, Open Economies Review 30, 759-777.

De la Cámara Arilla, C. (2000). "El teletrabajo, un indicador de cambio en el mercado de trabajo", Cuaderno de relaciones laborales 17, 227- 256.

Díaz Roldān, C. y Martínez López, D. (2006). "Inversión pública y crecimiento: un panorama", Hacienda Pública Española/Revista de Economía Pública, $n^{\circ} 176,2006,109-140$.

Dulcich, F. (2018). Desarrollo y adopciōn de tecnología: ¿la nueva dicotomía de la división internacional del trabajo? Cuadernos de Economía, 37(74), 315-352.

Greene, W. (2008). Econometric analysis. 6th ed., Upper Saddle River, N. J. Prentice Hall.

Helpman, E. (2004). The Mystery of Economic Growth, Harvard University Press, Cambridge, MA.

Hsiao, C. (2014). Analysis of Panel Data. Third edition. Cambridge University Press, New York.

International Labour Office, ILO (2019). World Employment and Social Outlook: Trends 2019, International Labour Office, Geneva.

Jones, C. and Romer, P. (2010). The new Kaldor facts: Ideas, institutions, population, and human capital, American Economic Journal: Macroeconomics 2 (1), 224-245, DOI: 10.1257/mac.2.1.224

Jorgenson, D. (2001). Information Technology and the US Economy, American Economic Review 91(1), 1-32. DOI: 10.1257/aer.91.1.1 
Jorgenson, D. and Stiroh, K. (2000). Raising the Speed Limit: U.S. Economic Growth in the Information Age. Brooking Papers on Economic Activity 1, 125-211. DOI: 10.1353/eca.2000.0008

Kaldor, N. (1961). "Capital Accumulation and Economic Growth" en F. Lutz y D. Hague (eds.), The Theory of Capital, Macmillan, Londres.

Kay, N. and Vanborren, W. (2018). "Is Digitalisation Changing Labour Markets? And what Statistics Are Needed to Help Policy Makers?", in Power from Statistics: data, information and knowledge OUTLOOK REPORT 2018 edition, Eurostat, European Union, pp. 151-156.

Miller, S..and Russek, F. (1989)."Are the Twin Deficits Really Related?", Contemporary Economic Policy 7(4), 91-115

OMS (2020a). COVID-19: Cronología de la actuación de la OMS. https://www. who.int/es/news-room/detail/27-04-2020-who-timeline---covid-19

OMS (2020b). Alocuciōn de apertura del Director General de la OMS. Rueda de prensa sobre la COVID-19 celebrada el 11 de marzo de 2020. https:// www.who.int/es/dg/speeches/detail/who-director-general-s-openingremarks-at-the-media-briefing-on-covid-19--11-march-2020

OMS (2020c). Report of the WHO-China Joint Mission on Coronavirus Disease 2019 (COVID-19) https://www.who.int/docs/default-source/coronaviruse/ who-china-joint-mission-on-covid-19-final-report.pdf?sfvrsn = fce87f4e_2

Pianta, M. (2018). "Technology and Employment: Twelve Stylised Facts for the Digital Age", The Indian Journal of Labour Economics. 61, 189-225

Reuveny, R. and Thompson, W. (2001). "Leading sectors, lead economies, and economic growth", Review of International Political Economy 8:4, 689-719

Thirlwall, A. (1979). "The Balance of Payments Constraint as an Explanation of International Growth Rate Differences", Banca Nazionale del Lavoro quarterly review $128,45-53$.

Valle, E. (2020). "La reacción de la Uniōn Europea ante el Covid-19", Fundaciōn de Estudios de Economía Aplicada, FEDEA, Apuntes no. 2020-03, Madrid.

Zeira, J. (1998). Workers, Machines, and Economic Growth. The Quarterly Journal of Economics 113 (4), 1091-1117 